\title{
2
}

\section{THE LONG-TERM EFFECTS OF GENDER QUOTAS IN BELGIUM}

\section{Leading by example?}

\author{
Robin Devroe, Silvia Erzeel, Petra Meier and \\ Bram Wauters
}

\subsection{Introduction}

Although many international studies might credit Scandinavian countries for their good practices in promoting gender equality in politics, Belgium undoubtedly features as a close second. Indeed, while the country initially took a slow start in granting women political rights (the adoption of universal suffrage for women, for instance, came rather late [Meier, 2012a]), it succeeded in building an international reputation for itself from the mid-1990s onward (Meier, 2012a). This reputation is closely intertwined with Belgium's extensive experiences with gender quotas. In 1994, Belgium became the first country in the world to adopt legislative gender quotas for all parties competing in elections and on all levels of government. In the following decades, new quotas acts were progressively adopted and implemented. The 2002 gender quotas acts, which required all Belgian parties to place an equal number of men and women on candidate lists and among the top two positions of each list, were unparalleled both in terms of ambition and effectiveness. More recently, the Brussels and Walloon regional governments adopted the zipper principle demanding the alternation of men and women across the entire candidate lists in local and regional elections.

This chapter analyzes the effects of gender quotas since they have first been adopted a quarter century ago. International scholarship on gender quotas has boomed in recent years, and many scholars have devoted time and attention to understanding the effects of these rules (Krook, Piscopo, \& Franceschet, 2012). Gender quotas may improve the descriptive and substantive representation of women, provide for female role models in politics and increase trust in political institutions. One key remaining question, however, is what kind of long-term effects, if any, gender quotas generate. By design, quotas have the potential to remove structural barriers for women and lead to a sustainable 
gender transformation in politics (Lang, Meier, \& Sauer, Forthcoming). In practice, quotas seem to generate mixed effects (Krook \& Zetterberg, 2017). Gender quotas, like other institutional reforms, may need time to achieve the desired outcome, but because they are relatively new reforms, we know little about their long-term impact. In this sense, Belgium presents itself as a unique case. Due to its quarter century of quotas experience, it offers a unique opportunity to assess the long-term effects of gender quotas and provides a good starting point for comparative research.

In a first instance, gender quotas target descriptive representation. To that end, most studies look at the increase of the number of women candidates and women elected. This chapter will take a more nuanced look at descriptive representation, by addressing four different aspects of it, more precisely: (1) the numerical effect, (2) the turnover effect, (3) the diversity effect and (4) the power effect. First, we consider whether gender quotas have led to an increase in the number of women elected in Belgium, an indicator that has received most scholarly attention so far. Quotas are often considered a 'fast track' to women's political representation but the question is whether they lead to both direct change and continued growth over the years. Related to this is a second expected effect, namely, on gendered turnover. Quotas are structural measures aimed at removing barriers for women in politics. While their key goal is to bring more women in politics, we ask whether they also keep women in politics. Third, we consider how gender quotas shape the level of diversity (in terms of age and level of education) within the group of women and men elected. Some scholars have argued that quotas might (re)produce withingroup inequalities and support the selection of some groups of women more than others (Hughes, 2011). We consider whether this is the case in Belgium. Finally, we discuss whether quotas stimulate women's access to positions of political power and, hence, whether they help women shatter the highest glass ceilings in politics: those of executive office and parliamentary party leadership. Addressing these four different aspects over a long time span will allow for understanding more precisely the effects of gender quotas on the descriptive representation of women.

\subsection{Gender quotas in Belgium: a quarter century experience}

The literature puts forward a number of explanations for the adoption of gender quotas, such as female/feminist agency (Dahlerup, 2006), the electoral system in place (Tremblay, 2012) and party competition (Kittilson, 2006), often linking the issue to changes in institutions such as power relations or structures (Dahlerup \& Leyenaar, 2013). The Belgian case is no exception in this respect, as the highly proportional list system facilitated the adoption of gender quotas, and the women/feminist activists and party competition largely contributed to this achievement (Meier, 2012a). 
However, one important explanation for the early adoption of gender quotas in Belgium is exceptional, at least within the European context. As Dahlerup (2006) argues, especially in Western Europe gender quotas tend to be a breach in the political system based on an abstract concept of equality and merit. Indeed, in countries such as France or Italy the adoption of gender quotas involved fierce debates on how they would violate or not concepts such as citizenship and equality. However, in Belgium they simply extended the dominant system ensuring salient sociodemographic groups with positions in political (and other) decision-making processes. Gender quotas tend to get adopted in countries characterized by egalitarian political cultures (Lovenduski \& Norris, 1993) and consociational or corporatist notions of group representation, especially where such measures exist for other groups (Dahlerup, 2006). While Belgium was not a very egalitarian society, the Belgian understanding of representation is intimately related to its consociational conception of citizenship and corporatist notions of group representation, which, in turn, are connected to the specific history of the Belgian state.

Belgium is a consociational democracy à la Lijphart (2012) that integrates social groups into processes of decision-making and the balanced representation of key social groups is an essential legitimizing feature of the political system. The federalization of Belgium from the early 1970s onward led to an increased institutionalized representation of the main language groups in the European Parliament, in the federal Senate and in the Parliament of the Brussels Capital Region. Similar arrangements were made for the federal government and for the government of the Brussels Capital Region (Pilet \& Pauwels, 2010). In sum, facilitating or guaranteeing descriptive representation is a common feature of the Belgian political system.

Whereas French or Italian protagonists of parity democracy and/or gender quotas had to question the basic model of citizenship and/or equality, Belgian activists mainly had to demonstrate that gender quotas fitted with the Belgian concept of representing citizens so as to extend existing measures to gender. The adoption of these rules can be seen as an extension of the prevailing model of citizenship, defining citizens in collective rather than individual terms and underlining the importance of group representation. Even though there was opposition to gender quotas, there were no valid arguments against them as the only possible argument - 'sex does not matter' no longer held in the 1990s (Meier, 2012a). While Belgium is an exception within Europe in this respect, it shows similarities with other systems across the globe, where dispositions for gender go hand in hand with those for ethnic, racial or religious groups.

While this particular feature of the Belgian political system definitely helps to explain the adoption of gender quotas in 1994 and 2002, it does not explain why only Brussels and Wallonia adopted more far-reaching gender quotas for their regional and local elections than did Flanders. However, here again, the features 
of the political system are important. Belgium is a small-scale highly competitive federal system. Wanting to play out their progressive character compared to a more conservative right-wing Flanders, Brussels and Wallonia could make a difference by adopting the most egalitarian type of gender quotas, a zipper principle applying to the entire list of candidates.

\subsection{The numerical effect: do gender quotas increase the number of women elected?}

After gaining more insight into the unique history of Belgium's electoral gender quotas, let us now consider their (long-term) effects, starting with the numerical effects and the question whether gender quotas have led to an increase in the number of women elected.

Before the adoption of the first gender quotas acts in 1994, Belgium scored rather poorly in international rankings of gender equality in political decision-making. Especially compared to other countries in Western Europe, ${ }^{1}$ the country lagged behind in respect to women's political representation (see also Figure 2.1(a) and (b) below). In 1991, 9\% of the elected representatives in the Belgian Chamber of Representatives (i.e. the Lower House) were women. This percentage was (much) lower compared to some of its neighboring countries with proportional representation or mixed-member electoral systems, including the Netherlands (21\%), Germany (21\%) and Luxembourg (13\%). It was higher than the percentage of women in two other neighboring countries, France and the United Kingdom, but these two countries apply majority rule which is known to be overall less conducive to a gender-balanced representation (Norris, 2004).

From the mid-1990s onward, women's presence in Belgian politics began to increase, and significantly so over time, as shown both in Figure 2.1(a) and (b) and in Table 2.1. Today, Belgium constitutes one of the frontrunners in women's numerical representation in Europe. Most elected assemblies at the national and regional level have more than $40 \%$ of women elected in the current period. In addition, Belgium also features among the countries that have made most progress since 1991. In the Belgian Chamber of Representatives, the largest elected assembly in the country, the number of women grew from a meager 9\% in 1991 to 41\% in 2019. This comes down to a growth rate of $304 \%{ }^{3}$. When we compare this to the growth rates in the other 17 countries in Figure 2.1(a) and (b), Belgium 'performs' quite well: the average growth rate of women elected is $104 \%$ in countries without legally binding gender quotas (following a so-called incremental path) and $269 \%$ in (so-called fast track) countries with such quotas. Belgium also 'outperforms' most 'fast-track' countries, with the exception of France (475\% growth rate) and Portugal (310\% growth rate), but the percentage of women in the starting year of 1991 in those countries was lower than that in Belgium.

However, the question of whether gender quotas have directly caused this numerical change in women's representation in Belgian politics does not have 

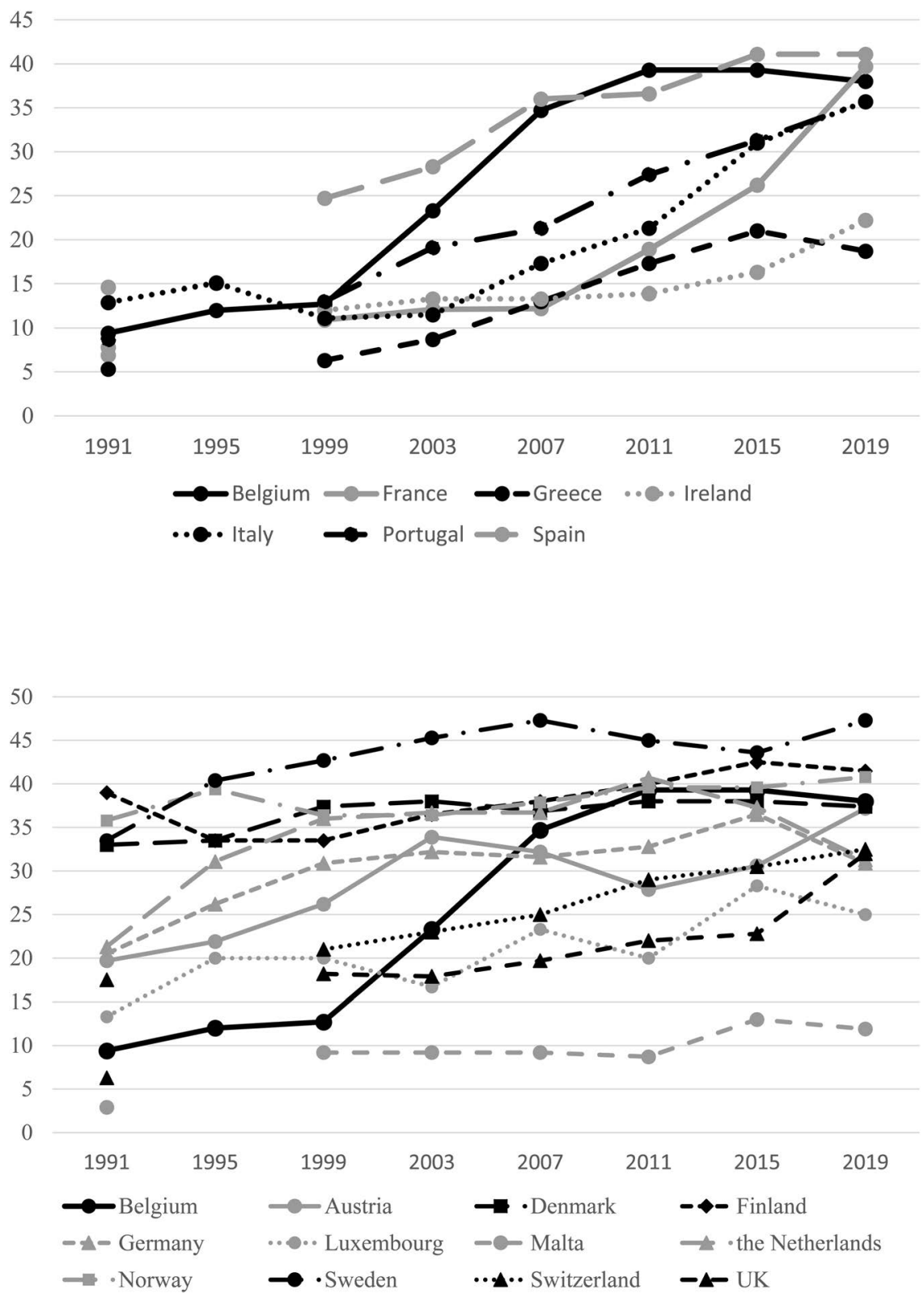

FIGURE 2.1 Percentage of women in national/federal lower houses in Western Europe (1991-2019) countries (a) with and (b) without legally binding gender quotas

Source: Data after 1997: http://archive.ipu.org/wmn-e/classif-arc.htm, data before 1997: http:// archive.ipu.org/PDF/publications/women45-95_en.pdf (both accessed on 16 July 2020). 
32 Robin Devroe, Silvia Erzeel, Petra Meier et al.

TABLE 2.1 Percentage of women elected at the federal and regional level in Belgium (1991-2019)

\begin{tabular}{|c|c|c|c|c|c|c|c|c|c|c|}
\hline & 1991 & 1995 & 1999 & 2003 & 2004 & 2007 & 2009 & 2010 & 2014 & 2019 \\
\hline \multicolumn{11}{|l|}{ Federal level } \\
\hline $\begin{array}{l}\text { Chamber of } \\
\text { Representatives }\end{array}$ & $9 \%$ & $12 \%$ & $19 \%$ & $35 \%$ & & $37 \%$ & & $39 \%$ & $39 \%$ & $41 \%$ \\
\hline Senate` & $11 \%$ & $30 \%$ & $30 \%$ & $38 \%$ & & $30 \%$ & & $43 \%$ & / & I \\
\hline \multicolumn{11}{|l|}{ Regional level } \\
\hline $\begin{array}{l}\text { Flemish } \\
\text { Parliament }\end{array}$ & & $18 \%$ & $20 \%$ & & $32 \%$ & & $41 \%$ & & $44 \%$ & $47 \%$ \\
\hline $\begin{array}{l}\text { Walloon } \\
\text { Parliament }\end{array}$ & & $8 \%$ & $11 \%$ & & $19 \%$ & & $35 \%$ & & $40 \%$ & $41 \%$ \\
\hline $\begin{array}{l}\text { Parliament of the } \\
\text { Brussels-Capital } \\
\text { Region }\end{array}$ & & $27 \%$ & $35 \%$ & & $46 \%$ & & $44 \%$ & & $40 \%$ & $44 \%$ \\
\hline $\begin{array}{l}\text { Parliament of the } \\
\text { German- } \\
\text { speaking } \\
\text { Community }\end{array}$ & & $20 \%$ & $24 \%$ & & $24 \%$ & & $32 \%$ & & $36 \%$ & $36 \%$ \\
\hline
\end{tabular}

* This only concerns the directly elected senators. Since 2014, senators are no longer directly elected.

Source: Celis and Meier (2006); https://igvm-iefh.belgium.be/nl/activiteiten/politiek/cijfers (accessed on 16 July 2020).

an easy answer. Previous studies have shown that both the design of quotas and the 'fit' with the institutional context have moderated the effects of the gender quotas (Meier, 2012b). The adoption of the first gender quotas in 1994 did not immediately trigger a large shift in women's numerical representation at the 1995 elections, as shown in Table 2.1. The main problem resided in the design features of the 1994 quotas: although strict sanctions applied, the relatively low quotas percentage stipulated at 33\% and especially the absence of placement mandates limited any strong effects (Meier, 2012b). Women's presence in the Senate did increase more substantially in 1995 but this had less to do with the effective implementation of the gender quotas and more with the institutional changes that took place at the same time. In 1993, an institutional and electoral reform stipulated that senators would be elected in two larger, rather than 21 smaller, electoral districts. It was this increase in district/party magnitude that created new opportunities for women's representation (Meier, 2012b).

The 2002 gender quotas generated more effects, but here too, the success of the gender quotas interacted with a changing institutional context. The enlargement of the electoral districts and increasing party magnitude in the Federal Chamber of Representatives and the Flemish parliament, which was adopted in parallel in 2002, created an additional boost for women's political representation in these two assemblies (Meier, 2012b). District and party magnitude in the Walloon parliament remained smaller and the percentage of women increased more slowly, which suggests that the net effect of the gender quotas was perhaps 
more limited than initially hoped for. The additional 'zipper quota' rules, which were applied for the first time at the regional and federal level in 2019, also generated an overall limited effect, as party magnitude is very small in Wallonia.

One reason why effects of gender quotas are not always detected is because effects might only become more visible over time. Indeed, the overview in Table 2.1 shows that women's presence in most elected assemblies has continued to grow after 2003/2004, even in the absence of new quotas. This increase in the longer run speaks to recent studies showing that political actors (parties, candidates or voters) need time to adapt to new rules. Parties need time to develop new recruitment and selection strategies, female candidates need time to 'become known' and voters need time to get acquainted with unfamiliar faces (Wauters, Maddens, \& Put, 2014). These changes generally do not happen overnight and inevitably encounter opposition (Devroe, Erzeel, \& Meier, 2020). For instance, in the absence of legally imposed 'horizontal' quotas which take gender relations across all lists into account, it took some time for parties to select more women at the head of the list (Vandeleene, 2014) and for voters to cast more preference votes for women (Erzeel \& Caluwaerts, 2015). Both are, however, crucial steps in the election of women. In addition, some parties still report encountering difficulties with the recruitment of female candidates, in particular right-wing parties (Devroe et al., 2020). If anything, 25 years of quotas experience has gone some way in changing the way the main political gatekeepers think about gender equality in politics. Most, if not all, democratic parties underline the importance of guaranteeing a gender balance on candidate lists (Vandeleene, 2014). These changes in social norms have arguably also contributed to the increase in women's presence and to the effective implementation of gender quotas.

\subsection{The turnover effect: do gender quotas keep women in politics?}

Bringing in (more) women in parliament is a first crucial step to gender equality in politics but keeping them in parliament is equally important. After all, politicians who serve for a longer period of time in parliament have a higher chance of being promoted to senior positions and/or weighing heavily on the decision-making process (van de Wardt, Van Witteloostuijn, Chambers, \& Wauters, 2020). Gender quotas, in turn, do not only influence the election of women and men but (potentially) also their reelection. After all, they are part of a wider set of context factors that influence parties' strategic calculations about which candidates to support and reselect at the next election (Bacchi, 2006), and that inform candidates' reelection strategies and their decision whether or not to run again. Previous studies already show that women are more likely than men to be 'de-selected' by parties and to leave parliament involuntarily (Vanlangenakker, Wauters, \& Maddens, 2013). The question is whether quotas can remediate this gender bias. To assess this, we compare the reelection rates between men and women in Figure 2.2. 


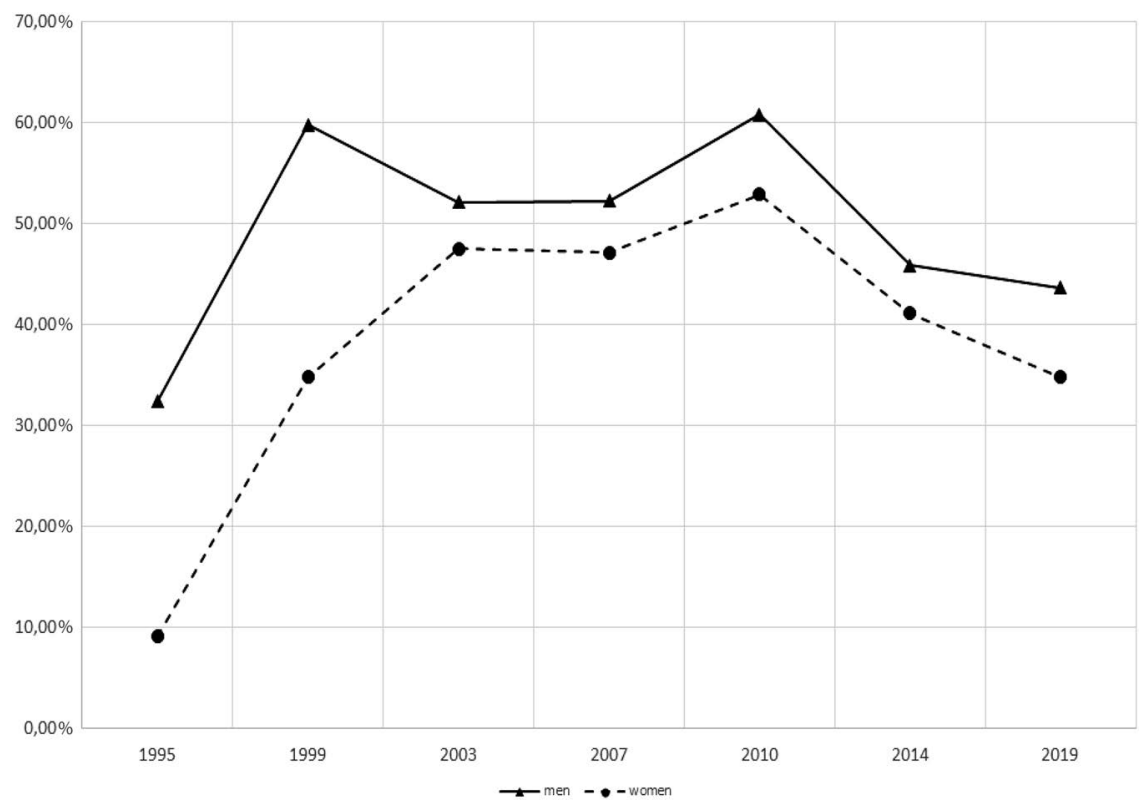

FIGURE 2.2 Reelection rate of incumbent MPs in the Federal Chamber of Representatives (1995-2019)

Source: Own calculations based on BE-Pathways data (Van Hauwaert \& Janssen, 2017) complemented with recent data from the official website of the Federal Chamber of Representatives (www.dekamer.be).

Reelection rates refer to the percentage of incumbent MPs that are also present in the next parliament. Figure 2.2 shows that before the introduction of the gender quotas, the reelection rate of women in the Federal Chamber of Representatives was extremely low. Only 9\% of women MPs that served during the 1991-1995 legislative term reentered the Federal Chamber in 1995. There are some reasons for this low reelection rate: due to a state reform, the total number of seats in the Federal Chamber was reduced from 212 to 150, and the regional parliaments were for the first time separately elected. ${ }^{2}$ Nevertheless, these elements also played for male MPs, and there, we see a reelection rate of more than $30 \%$, which is much higher than the percentage of women. This indicates that women suffered from a large turnover when quotas were used for the first time. Factors such as a male-dominated parliamentary and party culture and outgroup effects among male party selectors could be held accountable for this large turnover (Niven, 1998; van de Wardt et al., 2020). Indeed, some parties were ill prepared to deal with the increased demand for women and did little to rethink their recruitment and selection procedures to keep women in (Erzeel, Meier, \& Vandeleene, Forthcoming).

Despite this initial gender gap, we could expect that the initial outgroup effects disappear over time and that the reelection chances of women improve as 
party elites, voters and aspirant candidates become accustomed with women in politics (Wauters et al., 2014). This expectation is, however, not entirely met in Figure 2.2.

Furthermore, we do not witness a negative effect of quotas on reelection rates, even on the contrary. Both after the 1995-1999 term and after the 2003-2007 term (two terms when, respectively, the first quotas and more stringent ones were for the first time applied), we see an increase or a stabilization of the reelection rate of women, but definitely not a decrease. One could have expected that many women who were only put on the candidate lists to comply with the quota laws (as was common practice in some parties shortly after the introduction of quotas), would soon be leaving politics again but that is not what we see here. In other words, we do not find confirmation for 'quota women' being pushed toward the exit.

Over time, some fluctuations occur in the reelection rates of both men and women but these run remarkably parallel with each other. When new(er) parties obtain electoral success (such as in the last decade, which is characterized as increasingly volatile), reelection rates of both men and women MPs decrease. Two remarks can be made here: the large difference in reelection rates between men and women witnessed in the 1990s became smaller over time, but reelection rates of women continue to be systematically lower than those of men until today.

In sum, it seems that gender quotas did not create an important turnover effect. There is, however, still a gender gap in terms of turnover and this to the detriment of women.

\subsection{The diversity effect: do gender quotas increase diversity in politics?}

Another question is which women (and men) have entered parliament as a result of the introduction of gender quotas. Do gender quotas mainly benefit the representation of specific subgroups of (highly educated, young) women, or do quotas also help to diversify the population of women MPs? This is the question of intersectionality (Celis, Erzeel, Mügge, \& Damstra, 2014), which refers to the idea that experiences of inclusion and exclusion are not only gendered but also interact with other identity markers such as age, socio-economic status, race, ethnicity, ability, etc. Disadvantages can accumulate, e.g. lower educated women in politics might experience specific thresholds as women and as lower educated persons in politics, and these can further interlock when being combined. At the same time, the combination of identity markers adds to the relevance of their representation, as lower educated women might have specific interests that require specific representation, as they do not simply coincide with those of women nor of lower educated people. The question is whether quotas only bring more women into parliament, or whether they also encourage the (s)election of a more diverse group of women. 


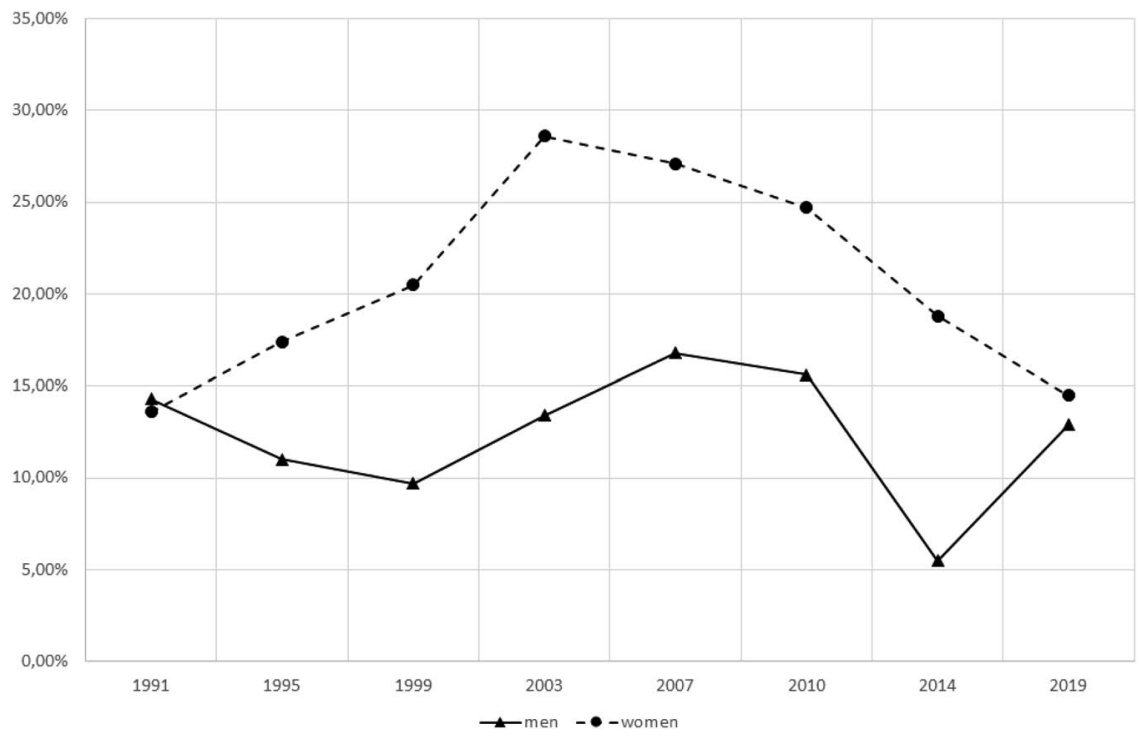

FIGURE 2.3 Share of MPs younger than 35 years by sex (Federal Chamber of Representatives, 1991-2019)

Source: Own calculations based on BE-Pathways data (Van Hauwaert \& Janssen, 2017) complemented with recent data from the official website of the Federal Chamber of Representatives (www.dekamer.be).

Figures 2.3 and 2.4 study the intersection between gender and age, and gender and education respectively. We focus on age and education in combination with gender for mostly pragmatic reasons: data on these characteristics are relatively straightforward to gather over time, while the intersection between gender and ethnicity has already been investigated elsewhere (Celis et al., 2014).

As for age, rather than looking at the average age, we investigate how well the youngest (below 35 years old) and the oldest age group (above 55 years old) are represented, whether this differs by sex, and how the introduction of quotas has impacted on this difference.

Figure 2.3 clearly illustrates that the introduction of quotas has granted more chances to young women aspiring a career in politics. While in 1991 (before the introduction of gender quotas), the share of young MPs was almost equal between men and women (about 15\%), the share of young women started to rise after the introduction of quotas. Especially in the 2003 elections, when the more stringent quotas were for the first time applied, the percentage of young women was high: about $30 \%$ of the women MPs were 35 years or younger. Although the percentage of young women MPs has slowly declined since then, the gap between men and women continued to be large and statistically significant (until 2019). Because we cannot find the same evolutions for male MPs, we can state quite safely that quotas have helped younger women to cross the parliamentary threshold. 


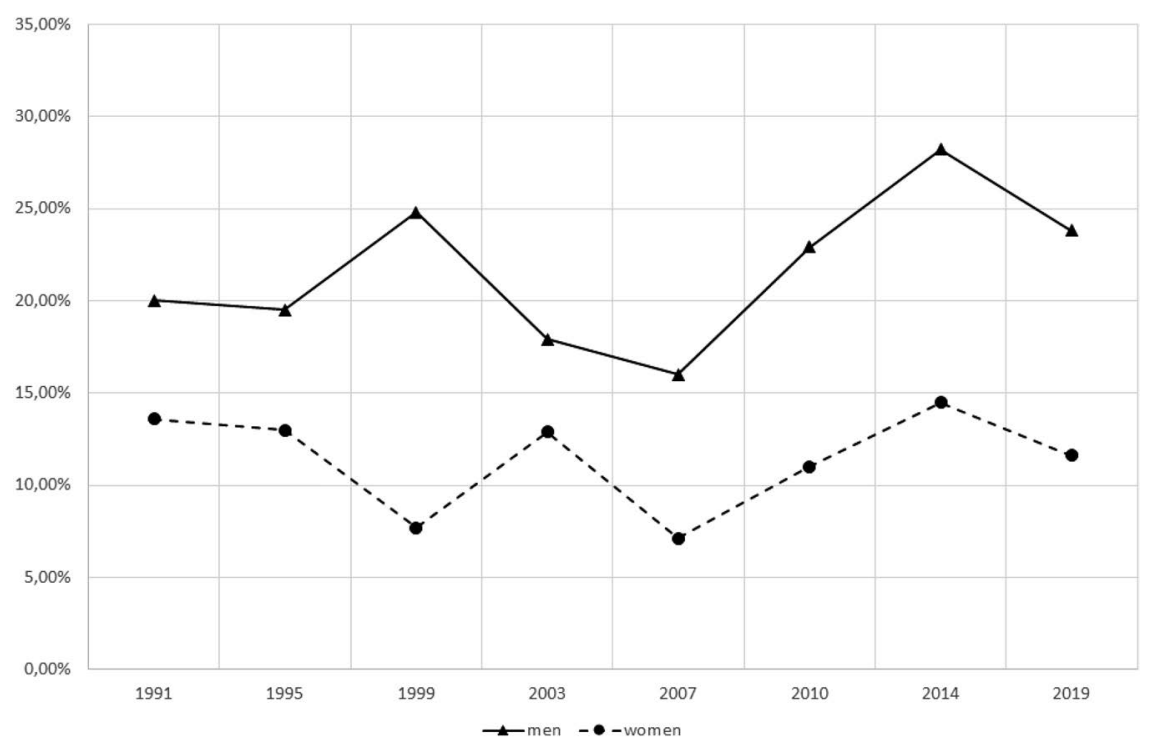

FIGURE 2.4 Share of MPs older than 55 years by sex (Federal Chamber of Representatives 1991-2019)

Source: Own calculations based on BE-Pathways data (Van Hauwaert \& Janssen, 2017) complemented with recent data from the official website of the Federal Chamber of Representatives (www.dekamer.be).

It is furthermore remarkable that since the first application of the quotas in 1995, the percentages of young MPs have differed between men and women but have become similar in the most recent elections (as it was in 1991 before the introduction of quotas). It remains yet to be seen whether the same picture will emerge in the next elections.

While quotas have facilitated the influx of young women into parliament, this is not the case for older women (aged 55 years and older). This becomes apparent from Figure 2.4. The share of older people among women MPs has always been lower than among men MPs, and this continues to be the case over the last 25 years. There are some fluctuations (which remarkably coincide between men and women) but no general (upward) trend can be noted. This leads to the conclusion that while quotas might have helped younger women, this is not the case for older women. This could be explained by the so-called complementarity advantage (see also Celis et al., 2014): when party selectors want to launch new faces on the candidate lists, it is an attractive option to select a candidate that is both young and female, as it simultaneously realizes rejuvenation and feminization of the candidate lists.

When it comes to educational attainment, we distinguish between MPs with and without a degree of higher academic education. This distinction is most relevant in a parliamentary system which is increasingly described as a 'diploma democracy' (Bovens \& Wille, 2017) in which MPs with a university degree increasingly prevail. 


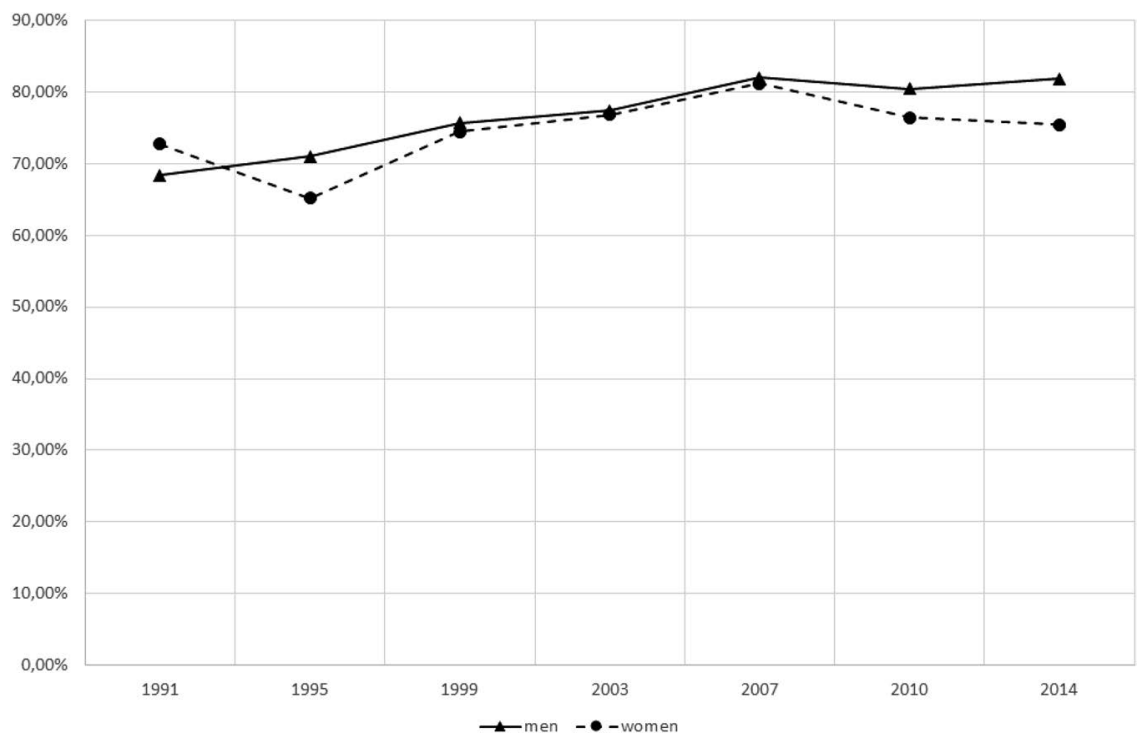

FIGURE 2.5 Share of MPs with a degree of higher academic education by sex (Federal Chamber of Representatives 1991-2014) ${ }^{4}$

Source: Own calculations based on BE-Pathways data (Van Hauwaert \& Janssen, 2017) complemented with recent data from the official website of the Federal Chamber of Representatives (www.dekamer.be).

Figure 2.5 shows a small but steady increase of MPs with a university degree, both among men and women. The absolute percentages between men and women do not differ significantly, and this is the case throughout the whole period of analysis. Although there are slightly more fluctuations among women MPs, the general conclusion is that the introduction of gender quotas did not have an impact on the educational profile of MPs. Nor were lower educated MPs more selected due to a lack of other candidates (just after the introduction of quotas), neither did quotas bring a more balanced group of women (in terms of educational profile) into parliament (in the long run).

In sum, it appears that quotas did not lead to a more diverse group of women represented in parliament, with the notable exception of young women who enjoyed more opportunities to start a national political career.

\subsection{The power effect: do gender quotas bring more women in political power?}

The final question that remains is whether gender quotas, and the consequent rise in the number of women MPs they encouraged, also increased women's access to positions of power. Focusing on two specific positions of power, this section considers the evolution in the number of female parliamentary party 


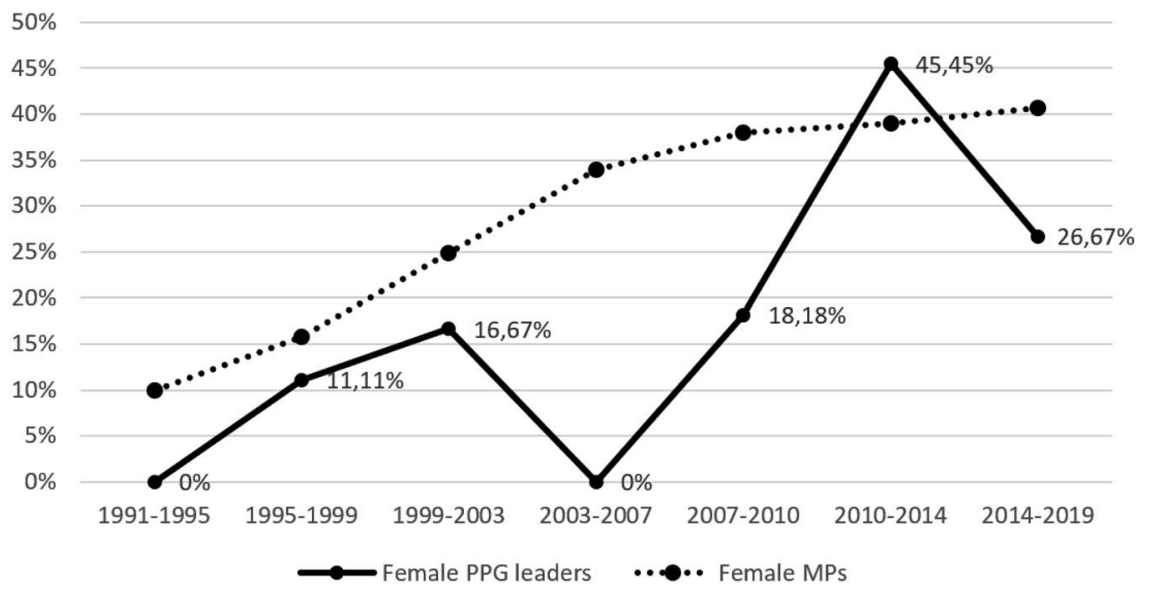

FIGURE 2.6 Female PPG leaders in the Federal Chamber of Representatives (1991-2019)

Source: de Vet (2019) and https://rosavzw.be/site/kwesties/politieke-participatie/in-belgie (accessed on 10 July 2020).

group leaders (PPG leaders) in the Federal Chamber of Representatives and the number of female ministers in the Federal government since 1991.

First, PPG leaders are pivotal players in parliament. They not only manage parties' legislative branches, coordinate backbenchers' specialized activities and ensure group unity, but they also promote political stability, decisional efficiency and parties' collective accountability to the electorate (de Vet, 2019). Figure 2.6 presents the evolution in the percentage of female PPG leaders per legislative term in the Federal Chamber of Representatives from 1991 onward. The dotted line presents the percentage of female MPs. As becomes clear from this figure, women are highly underrepresented among the PPG leaders. The historical underrepresentation of women in parliament logically also reduces the recruitment pool from which female PPG leaders could be selected. Yet, the percentage of female PPG leaders is in all cases but one far below the level of female MPs. This seems to point toward an additional funnel hampering the progression of women to leadership positions. The percentage of female PPG leaders peaked in 2010 with $45 \%$ but never reaches the 50\% threshold and keeps showing distinct trends downwards in recent years.

Second, being a cabinet member is among the most powerful political positions. On top of the electoral gender quotas, it is also stipulated in law that all governments, both federal and regional, must include at least one woman. However, women have traditionally also been underrepresented among government ministers. Figure 2.7 presents the evolution in the percentage of female members of the federal government from 1991 onward, compared to the percentage of female MPs. In the 1990s, female members of Cabinet were rather exceptional but this number has steadily increased over the years. Yet, the share 


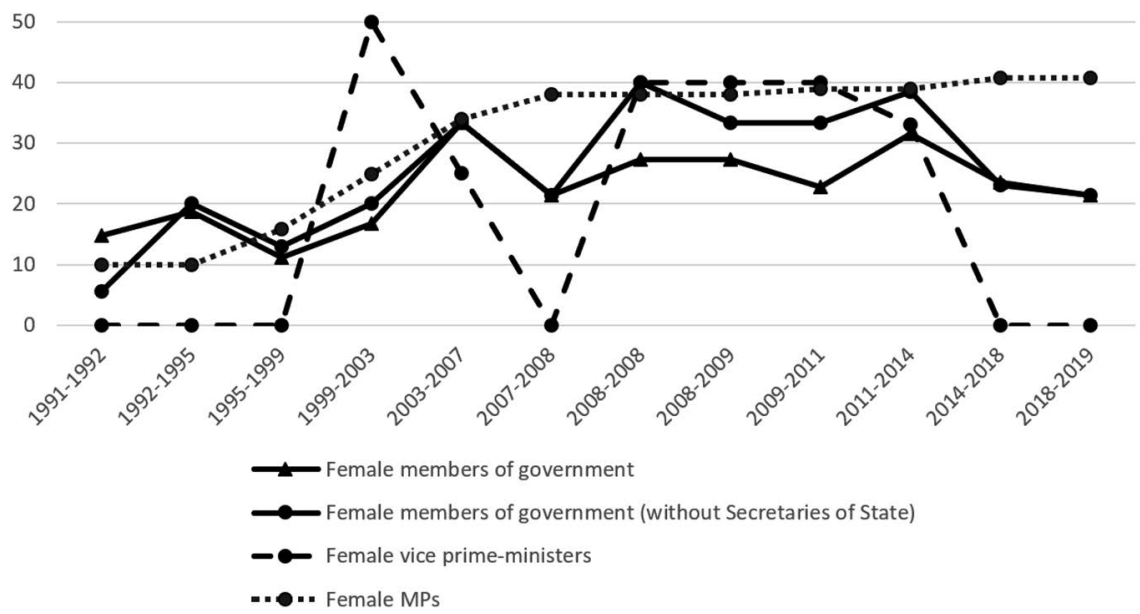

FIGURE 2.7 Female members of the Federal government (1991-2019)

Source: www.commisionroyalehistoire.be/belelite/nl/gov/governmentsoverview/fed (accessed on 10 July 2020).

of female ministers has never exceeded the 33\% percentage level and remains far below the level of female MPs. Looking at the number of female deputy prime ministers, a large fluctuation over time can be noted. The positive figures displayed between 2008 and 2014 are strongly linked to two female members of government (Laurette Onkelinx [PS] and Joëlle Milquet [cdH]) who served as deputy prime minister in several successive governments. However, here again a downward trend can be noted in recent years.

Taken together, these analyses clearly highlight that although women's numerical presence has increased over the years, this does not automatically result in high-level political positions being more open to or easier to reach for women. Despite the positive evolution observed in the number of female elected representatives, the highest echelons of power remain largely reserved for male politicians.

\subsection{Conclusion}

Belgium played a frontrunner role in the adoption of electoral gender quotas. By offering a reflection on Belgium's quarter century experiences with these gender quotas and considering their long-term effects, this chapter laid bare the extent to which the provision of electoral gender quotas has actually contributed to the descriptive representation of women.

A first part of our analyses focused on the numerical effect by assessing whether gender quotas have led to an increase in the number of women elected. Our results point out that from the mid-1990s onward, women's presence in the Federal Chamber of Representatives has significantly increased over time. In 
terms of growth rates, Belgium outperforms most other 'fast-track' countries. However, establishing a causal link between the implementation of gender quotas and this remarkable increase in women's numerical presence remains difficult as both the design of the quotas and the fit with the institutional context are found to have a moderating effect in this regard (Meier, 2012b).

Although the key goal of gender quotas might be to bring more women in politics, keeping them in parliament is an equally important target. We therefore also considered the turnover effect. Our results show that the 'revolving door' idea (according to which selectors select women only to comply with quotas increasing the likelihood of an early departure) does not hold. A comparison of the reelection rates of female and male MPs does not point to a negative effect of quotas on reelection rates, even on the contrary. Quotas helped to keep more women in politics over time, although female MPs are still more likely to exit than men.

By investigating what kind of women have entered parliament, we shed light on the diversity effect. Our analyses reveal that the introduction of quotas has helped younger women to cross the parliamentary threshold. A different picture, however, arises when looking at older women. They are still largely underrepresented (especially in comparison to their male colleagues). Also, in terms of education, the introduction of gender quotas did not have an impact on the profile of MPs: almost all male and female MPs have a university degree. This makes us conclude that quotas tend to reproduce within-group inequalities.

We finally investigated whether gender quotas brought more women in political power. Focusing on PPG leadership and executive office, our results point out that the introduction of gender quotas did not help women in shattering the highest glass ceiling in politics. The fact that men continue to occupy the most 'visible' positions is not only unequal in itself but also enables them to generate more (media) attention. This in turn increases their chances of being reelected (Hooghe, Jacobs, \& Claes, 2015) and ultimately results in the preservation of the systematic underrepresentation of women in politics.

Taken together, this chapter shows that although gender quotas generate certain beneficial long-term effects for the descriptive representation of women, it remains questionable whether they truly lead to a sustainable gender transformation in politics (Lang et al., Forthcoming). An important question prevails whether the existing gender quotas will lead to a continued growth in women's presence in politics and to the removal of structural barriers for women's representation. This is not an easy prediction. While quotas do offer 'fast track' solutions, they do not guarantee linear and steady growth. In that sense, 'fast track' patterns resemble 'incremental' patterns to women's representation (Dahlerup \& Leyenaar, 2013). From a comparative perspective, we are currently witnessing a 'flattening' curve in countries that had relatively high percentages of women in 1991, such as the Scandinavian countries. Dahlerup and Leyenaar (2013) have described this phenomenon as 'saturation without parity': the percentage of women fluctuates at a relatively high level of elected women but never 
reaches a fully equal number to men. The question is whether gender quotas are capable of pushing the number of women behind this point of saturation. In most countries with gender quotas, the curve is still on the rise but Belgium might be an exception to this rule. Since 2011, the percentage of women in most elected assemblies at the federal and regional level has saturated around $40 \%$. It is difficult to predict whether the percentage of women will continue to level off or whether it will push to a higher level in the foreseeable future. However, there is a distinct possibility that gender quotas too lead to 'saturation without parity', even if they are effectively designed as is the case in Belgium.

\section{Notes}

1 Looking at Western Europe allows for comparing similar systems (i.e. established democracies with consolidated party systems).

2 The continuation of a political mandate in a regional parliament was not considered as a reelection in our analysis.

3 The growth rate was calculated as follows: ((proportion of women 2019 - proportion of women 1991)/proportion of women 1991) $\star 100$.

4 The Chamber of Representatives no longer systematically mentions the educational degree of MPs from the 2019 term onward. Therefore, our analysis for education ends in 2014.

\section{References}

Bacchi, C. (2006). Arguing for and against quotas: theoretical issues. In D. Dahlerup (Ed.), Women, Quotas and Politics. London: Routledge: pp. 32-51.

Bovens, M., \& Wille, A. (2017). Diploma Democracy: The Rise of Political Meritocracy. Oxford: Oxford University Press.

Celis, K., Erzeel, S., Mügge, L., \& Damstra, A. (2014). Quotas and Intersectionality: Ethnicity and Gender in Candidate Selection. International Political Science Review 35(1): 41-54.

Celis, K., \& Meier, P. (2006). De Macht van het Geslacht. Gender, Politiek en Beleid in België. Leuven: Acco.

Dahlerup, D. (2006). Women, Quotas, Politics. London: Routledge.

Dahlerup, D., \& Leyenaar, M. (2013). Breaking Male Dominance in Old Democracies. Oxford: Oxford University Press.

de Vet, B. (2019). Between party and parliament. In The Roles of Parliamentary Party Group Leaders in Partitocratic Belgium. Ghent: Ghent University - GASPAR.

Devroe, R., Erzeel, S., \& Meier, P. (2020). The Feminization of Belgian Local Party Politics. Politics of the Low Countries 2(2): 169-191.

Erzeel, S., \& Caluwaerts, D. (2015). Is It Gender, Ideology or Resources? Individual-Level Determinants of Preferential Voting for Male or Female Candidates. Journal of Elections, Public Opinion \& Parties 25(3): 1-19.

Erzeel, S., Meier, P., \& Vandeleene, A. (Forthcoming). 25 Years of gender quotas, still a man's world? Implementation in the Belgian case. In S. Lang, P. Meier, \& B. Sauer (Eds.), Implementing Gender Quotas in Political Representation: Resisting Institutions. London: Palgrave.

Hooghe, M., Jacobs, L., \& Claes, E. (2015). Enduring Gender Bias in Elite Positions: Media Coverage of Female MP's in Belgian News Broadcasts (2003-2011). The International Journal of Press/Politics 20(4): 395-414. 
Hughes, M. M. (2011). Intersectionality, Quotas and Minority Women's Political Representation Worldwide. American Political Science Review 105(3): 604-620.

Kittilson, M. C. (2006). Challenging Parties, Changing Parliaments: Women and Elected Office in Contemporary Western Europe. Columbus, OH: Ohio State University Press.

Krook, M. L., Piscopo, J. M., \& Franceschet, S. (2012). The Impact of Gender Quotas. Oxford: Oxford University Press.

Krook, M. L., \& Zetterberg, P. (2017). Gender quotas and women's representation. New Directions in Research. New York, NY: Routledge.

Lang, S., Meier, P., \& Sauer, B. (Forthcoming). Implementing Gender Quotas in Political Representation: Resisting Institutions. London: Palgrave.

Lijphart, A. (2012). Patterns of Democracy: Government Forms \& Performance in Thirty-Six Countries. New Haven, CT:Yale University Press.

Lovenduski, J., \& Norris, P. (1993). Gender and Party Politics. London: Sage.

Meier, P. (2012a). From Laggard to Leader: Explaining the Belgian Gender Quotas and Parity Clause. West European Politics 35(2): 362-379.

Meier, P. (2012b). The collateral damage of electoral system design. In M. Tremblay (Ed.), Women and Legislative Representation. New York, NY: Palgrave: pp. 137-147.

Niven, D. (1998). Party Elites and Women Candidates: The Shape of Bias. Women \& Politics 19(2): 57-80.

Norris, P. (2004). Electoral Engineering: Voting Rules and Political Behavior. New York, NY: Cambridge University Press.

Pilet, J.-B., \& Pauwels, T. (2010). De vertegenwoordiging van taalgroepen in België: de weg naar een hyperinstitutionalisering. In Gezien, gehoord, vertegenwoordigd? Diversiteit in de Belgische politiek. Ghent: Academia Press: pp. 47-68.

Tremblay, M. (2012). Women and Legislative Representation: Electoral Systems, Political Parties, and Sex Quotas. Basingstoke: Palgrave Macmillan.

van de Wardt, M., Van Witteloostuijn, A., Chambers, A., \& Wauters, B. (2020). Birds of a Feather Flock Together? The Survival of Underrepresented Groups within Parliamentary Parties, 1990-2015. European Journal of Political Research 60(2): 474-496.

Van Hauwaert, S., \& Janssen, C. (2017). Pathways to Power: The Political Representation of Citizens of Immigrant Origin in Belgium (BE-PATHWAYS). Cologne: GESIS Data Archive.

Vandeleene,A. (2014). Gender Quotas and 'Women-Friendly' Candidate Selection: Evidence from Belgium. Representation 50(3): 337-349.

Vanlangenakker, I., Wauters, B., \& Maddens, B. (2013). Pushed Toward the Exit? How Female MPs Leave Parliament. Politics \& Gender 9(1): 61-75.

Wauters, B., Maddens, B., \& Put, G.-J. (2014). It Takes Time: The Long-Term Effects of Gender Quota. Representation 50(2): 143-159. 